\title{
Antioxidant activity of Alginate Oligosaccharides (AOS) from Sargassum sp. for Improving the Cutaneous Wound Enclosure in Zebrafish (Danio rerio)
}

\author{
Jelita Rahma Hidayati ${ }^{*}$, Ervia Yudiati2,3, Delianis Pringgenies², \\ Zaneb M. Ben Mansur', Fadhliyah Idris' \\ 'Faculty of Marine and Fisheries Sciences, Raja Ali Haji Maritime University \\ Jl. Politeknik Senggarang Tanjung Pinang, Riau Island, Indonesia \\ 2Department of Marine Science, Faculty of Fisheries and Marine Science, Diponegoro University \\ 3Laboratory of Marine Micro/Microalgae Technology, Faculty of Fisheries and Marine Science, \\ Diponegoro University \\ Jl. Prof. H. Soedharto, SH., Tembalang, Semarang, Indonesia \\ 4Biologi Department, College of Education, Asmarya Islamic University \\ PO Box 495-471, Zliten, Misrata, Libya \\ Email: jelitarahmahidayati@umrah.ac.id
}

\begin{abstract}
Sargassum sp. classified as brown seaweed which is known as an alginophyte (alginate producer). Alginate has undergone a depolymerization process called alginate oligosaccharides (AOS) and has been shown to have antioxidant activities to increase wound tissue recovery. This study aimed to determine the antioxidant activity of Alginate oligosaccharides (AOS) and their ability to improve the cutaneous wound enclosure in Zebrafish (Danio rerio). The $\mathrm{IC}_{50}$ value was used to calculate the ability of extract to inhibit free radicals using DPPH $(516 \mathrm{~nm})$. Zebrafish were immersed 12 hours before the injury and shortly after injury with a two factorial design, i.e., alginate concentration and immersion time. Zebrafish were immersed for 1 hour, 3 hours, and 5 hours with serial concentration of 200 ppm, 400 ppm, and 600 ppm, respectively. Morphological observations were carried out at the the first day, fourth day, tenth day, and twenty-first-day post wounding. The results of this study showed that alginate from Sargassum sp. has a yield of $40.5 \pm 1.125 \%$ with a purity level of $89.95 \%$. Based on antioxidant activity, alginate is categorized as moderate (178,377 ppm) and evidently has the ability to increase wound recovery compared to control. It has indicated by the formation of the wound enclosure.
\end{abstract}

Keywords: Alginate Oligosaccharides, Antioxidant, Danio rerio, Wound recovery

\section{INTRODUCTION}

Sargassum sp. is one of the most abundant biological resource seaweed from Indonesia as alginophyte (alginate producer). Alginate is a natural polysaccharide commonly found in all brown algae species (Szekalska et al., 2016) and yielded up to $40 \%$ of the total dry weight (Yudiati and Isnansetyo, 2017). Alginate plays an essential role in maintaining the structure of algal tissues. The application of biotechnology to produce natural products from the sea is increasing rapidly due to the tendency of humans paradigm "back to nature". This tendency occurs because the products made from natural product do not cause side effects, nontoxic (Lin et al., 2015), biodegradable and valuable renewable products (Sylvia et al., 2020). In processing fishery products, alginate is used as glazing in freezing fish to avoid oxidation reactions (Laksanawati et al., 2017). Antioxidants are compounds or substances that can inhibit, delay, prevent or slow down oxidation reactions (Hidayati et al., 2019) and has the potential to be used in the wound healing process (Gong et al., 2013; Yang et al., 2016; Pandey et al., 2020; Comino-Sanz et al., 2021).

The wound disrupts normal conditions on the skin that causes loss of organ function, 
blood clotting, bacterial contamination, and cell death (Kozier, 1995). Wound healing occurs in three distinct and continuous phases, namely the inflammatory phase, the tissue formation phase (proliferation/reepithelization), which consists the formation of granulation tissue and fibroblasts, and the remodeling/recovery phase (Wang et al., 2017). Many antiseptic agents are commonly used to treat wound infections but can be toxic to the cells involved in the wound healing process. According to Nagoba et al. (2013), antiseptic agents such as iodine, chlorhexidine, hydrogen peroxide, alcohol, and betadine (povidone-iodine) can interfere the normal healing process, negatively impact fibroblasts and allow microbes to dominate. While $70 \%$ alcohol can damage healthy skin cells around the wound because the material has a mechanism of action as an antiseptic that damages cell walls, denatures proteins, and lyses cells in the alcohol-treated cells (McDonnel and Russel, 1999).

Alginate has a proinflammatory activity (Kezia el al., 2013) and also has antioxidant activity (Yudiati et al., 2018) that is needed to balance the levels of reactive oxygen species (ROS) in the body caused by stepping of wound inflammation stage (Arief \& Widodo, 2018). The inflammatory cells produce excess ROS and impacts the wound healing process (Kurahashi \& Fujii, 2015). According to Angelina et al. (2021), alginate can improve the wound enclosure process one day faster because it can increase pro-inflammatory cytokines, namely proteins that play an essential role in increasing the phagocytic function in the inflammatory process. The increment of phagocytosis in the inflammatory process will lead to the formation of fibroblasts and increased wound healing process (Kim \& Moudgil, 2017).

Zebra fish (Danio rerio) are used as models in wound recovery testing. According to Ko et al. (2011), zebrafish are used in many bioactivity screening studies due to their short life span, genome similarity to mammals, comparatively small size, and the ability of the female fish to produce a large number of eggs. The major steps and principles of cutaneous wound healing are conserved among adult mammals and adult zebrafish, it makes zebrafish a valuable model for studying vertebrate skin repair (Richardson et al., 2013) and cutaneous wound closure (Richardson et al., 2016). This study aimed to determine the antioxidant activity of Alginate oligosaccharides (AOS) and their ability to improve the cutaneous wound enclosure in Zebrafish (Danio rerio).

\section{MATERIALS AND METHODS}

\section{Alginate Oligosaccharides (AOS) extraction}

The Sargassum sp. sample was collected from Teluk Awur Waters, Jepara. Soon as came in to the laboratory, the samples were washed using fresh water and dried up at room temperature. The dried Sargassum sp. were extracted according to the methods by Yudiati \& Isnansetyo (2017). The alginate was then dried at $140^{\circ} \mathrm{C}$ for 5 hours to get the oligosaccharide (Yudiati et al., 2018).

\section{Fourier-Transform IR (FT-IR) spectroscopy}

The FT-IR spectra of alginates were recorded in the 4000-500 $\mathrm{cm}^{-1}$ region using a Thermo Nicolet 380 FTIR (Germany). Preparation was done by mixing the samples with $\mathrm{KBr}$ in pellets formation (10\% w/w) (Yudiati et al., 2018).

\section{Determination of DPPH Maximum Absorbance}

DPPH was weighed for $4 \mathrm{mg}$ and dissolved with $100 \mathrm{~mL}$ of methanol $(0.1 \mathrm{mM})$. The solution is homogenized and incubated for 120 mins in a dark place. After that, DPPH solution was taken $4 \mathrm{~mL}$, then put into the cuvette and observed the absorbance using a spectrophotometer (Shimadzu UV-1280) at 400-800 nm (Hidayati et al., 2017). The highest absorbance will then be used to measure antioxidant activity.

\section{The Assessment of Antioxidant Activity}

Antioxidant activity determination was carried out using spectrophotometric methods (Moubayed et al., 2017). A total of $4 \mathrm{~mL}$ of the test solution was added with $1 \mathrm{~mL}$ of DPPH 0.1 $\mathrm{mM}$. The solution was incubated for 30 minutes and then measured the absorbance at the maximum wavelength. The percentage of inhibition is calculated using the formula (Yudiati et al., 2018). 
The inhibition percentage data was plotted to constructed the linear regression equation and determined the $\mathrm{IC}_{50}$ value (Hidayati et al., 2020).

\section{Determination of Lethal Concentration 50 ( $\mathrm{LC}_{50}-24$ Hours)}

Alginate were dissolved in various concentrations $(125,250,500$, and $1000 \mathrm{ppm})$ using a magnetic stirrer and administered in 5 L. Thirty adult zebrafish were added to each aquarium. All treatments were applied in two replications. Observations on the mortality of the test animals were carried out at 0 hours, 0.5 hours, 1 hour, 2 hours, 4 hours, 6 hours, 8 hours, 16 hours, and 24 hours. Probit analysis was carried out in this study to determine the value of LC 50 using IBM SPSS 20 software.

\section{Skin injury and alginate immersion}

Twenty zebrafish were immersed in each treatment before being injured; then, the zebrafish were put into an aquarium containing clove oil (10\%) used as an anesthetic (Rahim, 2017). The fish is then cut with a hot looped iron and attached to the area around its dorsal fin. The zebrafish were then put back in the immersion medium according to the treatments. After the immersion treatment, zebrafish were maintained on standard media for 21 days (Richardson et al., 2013).

\section{RESULT AND DISCUSSION}

\section{Alginate Extraction}

Extraction of alginate from Sargassum sp. shows the average percentage alginate yield is $40.5 \%$ of the total dry weight (Table 1).

According to Yudiati and Isnansetyo (2017), the yield obtained is relatively high because alginate yield of the Sargassum sp. from other researchers ranges from 3.3 to $40.34 \%$. The percentage of alginate yield is influenced by several factors: the type of brown algae, habitat conditions, the temperature at extraction, and the concentration of materials used for the alginate extraction process (Yudiati \& Isnansetyo, 2017). The yield of alginate produced in this study was higher than the alginate extraction using the calcium method $(11.70 \pm 0.41 \%)$ and the acid method (9.95 $\pm 0.31 \%)$ (Maharani et al., 2018). The high percentage of alginate yield obtained was due to EDTA in the extraction process. EDTA is a water-soluble polyamine carboxylic acid and functions as a chelating agent (Yudiati et al., 2018). The addition of EDTA can increase the absorption capacity of metal ions (Sari et al., 2016), and resulting in more bonds of alginate compounds than alginate extraction without the addition of EDTA (Latifi et al., 2015). Polysaccharides generally have large molecules and are more complex than mono and oligosaccharides, making them difficult to dissolve in water. Therefore, oligosaccharides are carried out to facilitate the dissolution of alginate with water and increase its antioxidant activity (Rizfa et al., 2020).

\section{FT-IR Spectroscopic Analysis}

Alginate purity level was determined through Infrared Spectroscopy analysis using FTIR to compare the value of the deacetylation degree of the sample alginate with the alginate standard (Bastman, 1989).

The FTIR results (Figure $1 \mathrm{~b}$ ) showed that the extracted alginate had the same functional group as the standard alginate (Figure 1a) and had a purity level of $89.95 \%$. The FTIR results already meet the standards because alginate has three peak specifications: The spectra around $3200 \mathrm{~cm}^{-1}$ is signed of hydroxyl group (Bahar et al., 2012),

Table 1. Percentage alginate yield

\begin{tabular}{ccccc}
\hline No. & $\begin{array}{c}\text { Dried } \\
\text { Sargassum sp, (gram) }\end{array}$ & $\begin{array}{c}\text { Dried Alginate } \\
\text { (gram) }\end{array}$ & $\begin{array}{c}\text { percentage yield of } \\
\text { alginate (\%) }\end{array}$ & Average \\
\hline 1. & 20 & 8,27 & 41,35 & \\
2. & 20 & 8,20 & 41,00 & $40,5 \pm 1,125$ \\
3. & 20 & 7,85 & 39,25 & \\
\hline
\end{tabular}




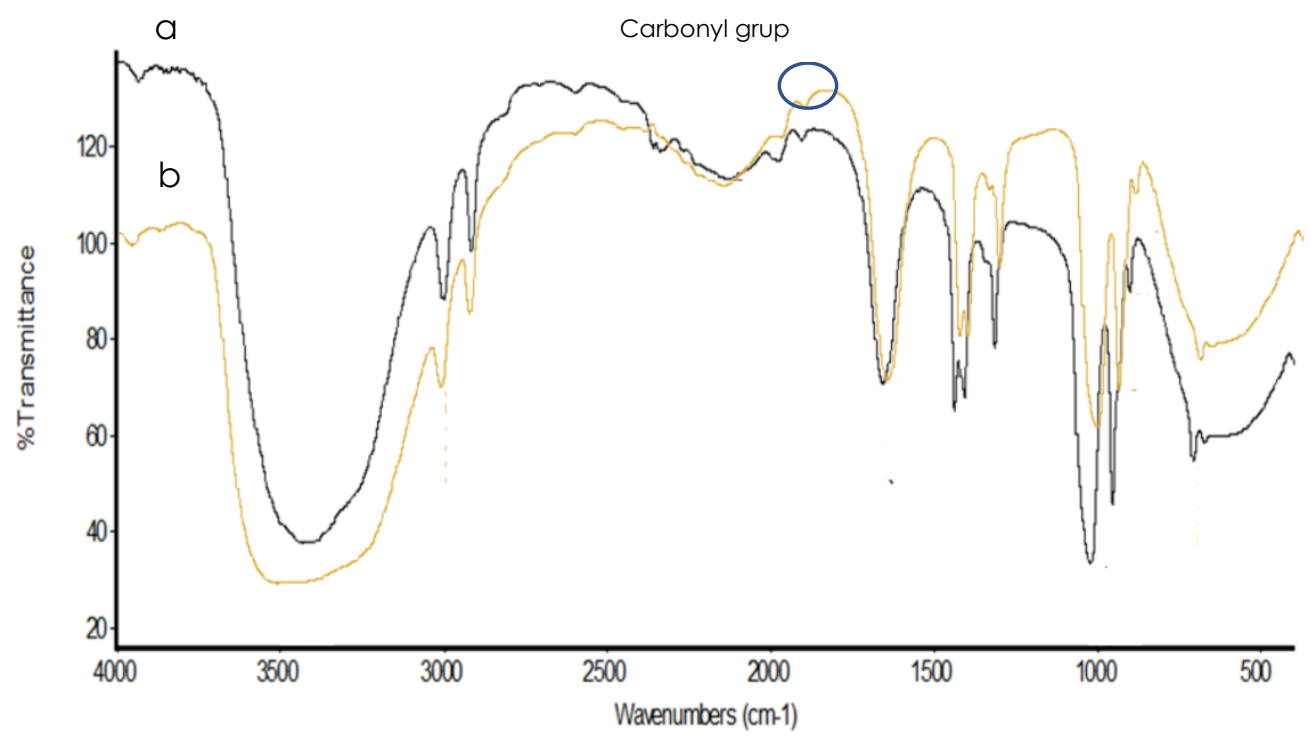

Figure 1. Standar alginate (a); Extraction alginate (b)

the spectra around $1600 \mathrm{~cm}^{-1}$ indicated of COO-asymmetry and $1400 \mathrm{~cm}^{-1}$ predicted of COO-symmetry (Maharani et al., 2017). Based on Yudiati et al. (2018) in the heat treatment carbonyl group were positively formed. Oligosaccharides contain glycosidic linkages (acetal or ketal) that release two or more monosaccharide units upon hydrolysis and can be produced by splitting of the glycosidic bonds. Alginate was heated at $60^{\circ} \mathrm{C}$ to break the glycosidic bonds. It was suggested that the attack of a hydrogen atom in position linked polysaccharides caused a division of the glycosidic bond, and consequently the formation of carbonyl groups (Soukaina et al., 2020).

\section{DPPH radical scavenging activity}

The maximum absorbance of DPPH was obtained at a wavelength of $516 \mathrm{~nm}$ (Rizfa et al., 2020). While, Hidayati et al. (2017) reported that the maximum DPPH absorbance was occurred at a wavelength of $514 \mathrm{~nm}$. This maximum wavelength was then used to test the antioxidant activity.

The results showed that alginate had an ${ }^{\prime} C_{50}$ value of 178.377 ppm and was classified as a moderate antioxidant (Jun et al., 2003). In this research, The $\mathrm{IC}_{50}$ value was slightly higher than heat-degraded alginate (40.86 ppm) and lower than heat-degraded alginate (196.15 ppm) (Rizfa et al., 2020). Therefore, the lower value of $\mathrm{IC}_{50}$ indicates a higher antioxidant activity (Sivaraman et al., 2013). The process of inhibiting free radicals is carried out by taking electrons from antioxidant compounds so that free radicals become stable (Sayuti \& Yenrina, 2015). Antioxidants are compounds or substances that can inhibit, delay, prevent or slow down oxidation reactions (Hidayati et al., 2019) and has the potential to be used in the wound healing process (Comino-Sanz et al., 2021).

\section{Lethal Concentration 50 ( LC $_{50-24}$ Hours)}

Determination of Lethal Concentration 50 (LC50-24 Hours) was carried out to determine the concentration of the extract that could kill $50 \%$ of the test organisms and determine the concentration to be used for further testing. The results showed that the highest mortality of Zebrafish was found at a concentration of 1000 ppm alginate, with 17 deaths within 24 hours. The probit analysis results showed that the proper concentration range for alginate immersion was <955.714 ppm with an immersion time of $<24$ hours. Based on this data, we have chosen the immersion concentration applied were $200 \mathrm{ppm}$ (A), 400 ppm (B) and 600 ppm (C) with an immersion time of 1 hour (I), 3 hours (II) and 5 hours (III), respectively. 


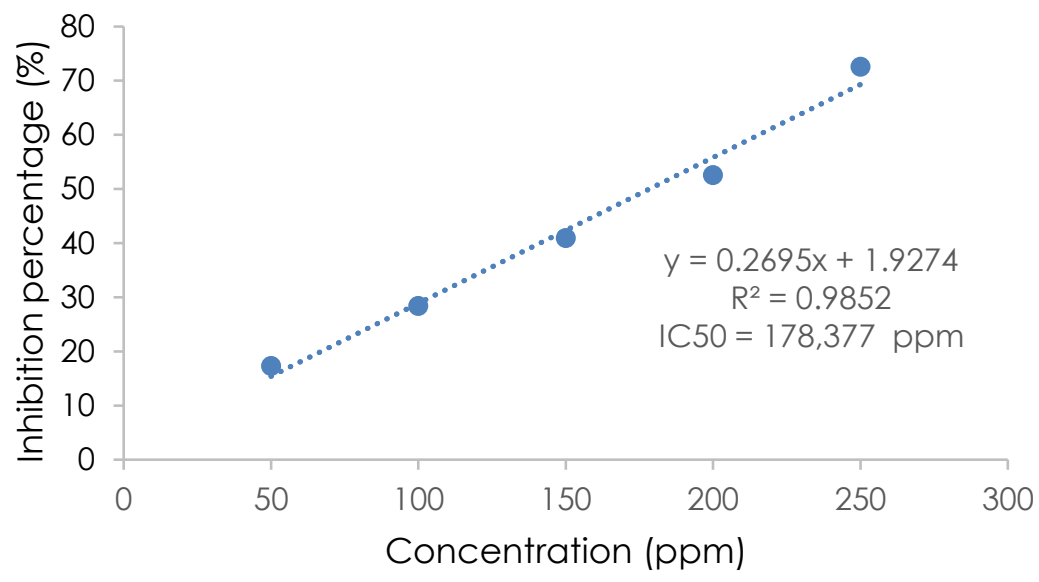

Figure 2. Antioxidant activities of Alginate oligosaccharide (AOS) from Sargassum sp.
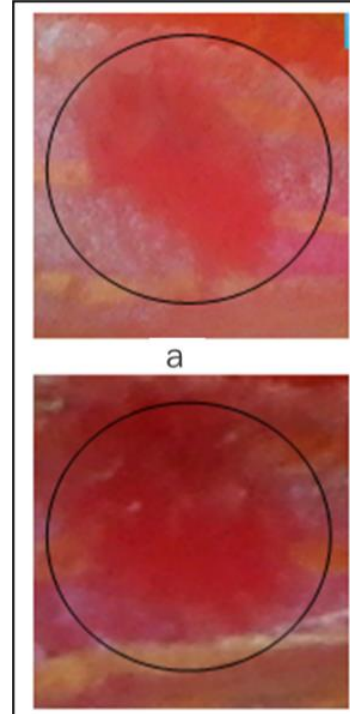

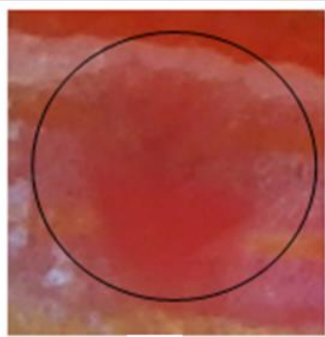

b

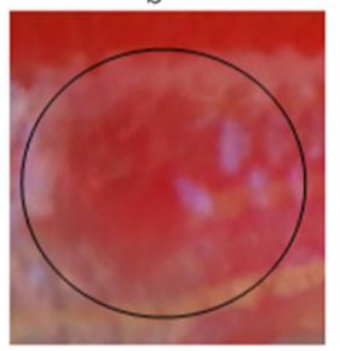

d

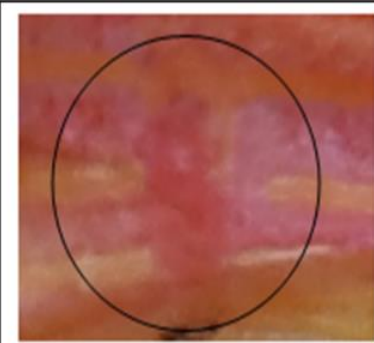

a

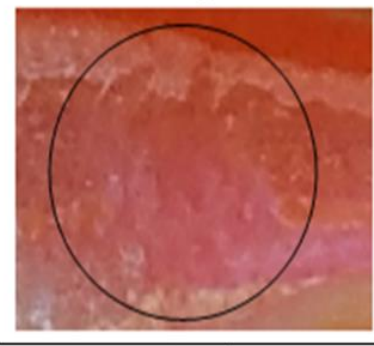

C

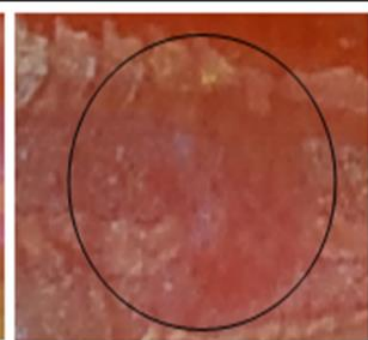

b

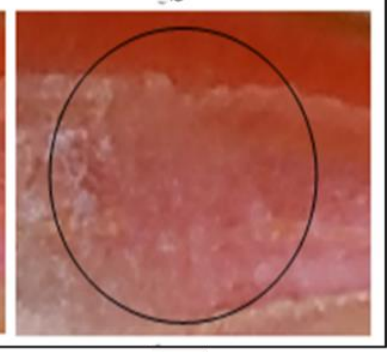

d

A

B

Figure 3. Cutaneous wound healing models in adult zebrafish A (First day post wounding) B (21 days post wounding) ( $a=$ Negative Control; $b=$ Immersed for 5 hours in alginate with $a$ concentration of $200 \mathrm{ppm} ; \mathrm{c}=$ Immersed for 5 hours in alginate with a concentration of 400 ppm; $d=$ Immersed for 5 hours in alginate with a concentration of 600 ppm.)

\section{Cutaneous wound healing}

The results showed that the samples were immersed for 5 hours with a concentration of 200 ppm (AllI), 400 ppm (BIII), and 600 ppm (CIII) treatments had the best results and used to represent the description of wound healing with alginate morphologically. Morphological observation of wounds was carried out as an indicator of wound healing as seen from wound closure in zebrafish (Figure 3).
Morphologically, the appearance of wounds for all treatment groups was still exposed and showed widening of the wound due to the inflammatory response on the first day. However, the wound edges for all treatments began to get narrower in the next day, though wound enclosure has not appeared yet. Twenty-four hours after injury, the control and treatment groups (immersed for 5 hours) in each concentration (200 ppm (AIII), 400 ppm (BIII), and 600 ppm (CIII)), did not 
Table 2. Percentage of wound enclosure (\%)

\begin{tabular}{cccc}
\hline Immersion time & 200 (A) & Concentration (ppm) & $600(\mathrm{C})$ \\
\hline 1 hour (I) & $28 \pm 0,035 \%$ & 600 (B) & $70 \pm 0,141 \%$ \\
3 hours (II) & $50 \pm 0,141 \%$ & $28 \pm 0,212 \%$ & $65 \pm 0,071 \%$ \\
5 hours (III) & $53 \pm 0,177 \%$ & $70 \pm 0,141 \%$ & $83 \pm 0,035 \%$ \\
\hline
\end{tabular}

show any difference. In addition, the wound on the zebrafish skin was still clearly visible. Morphological observation of the wound on the last day of maintenance showed that the treatment group Alll, BIII and CIII showed scab formation covering the scar. In contrast, the wound was still open in the control group, and the scab did not appear to cover the wound completely. However, the scars in the controls were minor in size compared to the previous days. In addition, there was no sign of infection in the wound group until the $21^{\text {st }}$ day of observation.

Table 2 showed that samples immersed for 5 hours with a concentration of 600 ppm (CIII) had the best results based on the wound enclosure indicators. After 21 days, it can cover $83 \%$ of its wounds, compared to samples immersed for 5 hours with a concentration of 200 ppm (Alll), which only covers $28 \%$ of its wounds. The wound healing process in alll treatment had taken longer time than CIII treatment. According to Aponno et al. (2014), the active ingredients' concentration, including antioxidant properties, is essential in wound healing.

Wound healing is a complex dynamic process. In the early phase of the inflammatory reaction, neutrophils and macrophages will enter the damaged or injured tissue, and these cells will produce Reactive Oxygen Species (ROS). ROS are also produced in the proliferative phase and play an essential role in intracellular signalling in response to various extracellular stimuli (Arief \& Widodo, 2018). However, excessive ROS production can cause tissue damage and interfere with the wound healing process because it can interfere with communication between cells. Therefore, antioxidants play an important role in removing ROS in wound healing.

\footnotetext{
Alginate is known to have the ability to induce monocyte cells and stimulate
}

macrophages so this will increase the production of pro-inflammatory cytokines (Kezia et al., 2013) to accelerate the wound healing process. According to Angelina et al. (2021), alginate with a concentration of $0.1 \%$ was succeeded to accelerate the wound healing process. Furthermore, according to Wang et al. (2015), alginate can fasten the wound healing by increasing type I collagen. Thus, the alginate in this study was managed to accelerate the wound healing process. Alginate is a promising agent as an alternative for the new types of natural wound medicine.

\section{CONCLUSION}

The results of this study showed that alginate from Sargassum sp. has a yield of 40.5 $\pm 1.125 \%$ with a purity level of $89.95 \%$. Alginate has a moderate category of antioxidant activity $(178,377 \mathrm{ppm})$ and has the ability to increase wound recovery compared to control. It is indicated by the enclosure of the wound formed.

\section{ACKNOWLEDGMENT}

The author would like to thank the Ministry of Research and Technology for providing research funds with contract number 258-08/UN7.P4.3/PP/2019.

\section{REFERENCES}

Angelina, C.A., Yudiati, E., \& Pringgenies, D. 2021. Potential of Sodium Alginate in Sargassum sp. in Lotion Preparation to Treat Incision Wound in Mice. Journal of Biology \& Biology Education., 13(1):99-105. doi: 10.15294/biosaintifika.v13i1.22539

Aponno, J.V., Yamlean P.V.Y., \& H.S. Supriati. 2014. Uji Efektivitas Sediaan Gel Ekstrak Etanol Daun Jambu Biji (Psidium guajava Linn) terhadap Penyembuhan Luka yang Terinfeksi Bakteri Staphylococcus aureus 
pada Kelinci (Orytolagus cuniculus). Jurnal Ilmiah Farmasi., 3(3):279-286. doi: 10.35799/pha.3.2014.5444

Arief, H. \& Widodo, M.A. 2018. Peranan Stres Oksidatif pada Proses Penyembuhan Luka. Jurnal IImiah Kedokteran Wijaya Kusuma., 5(2):22-29. doi: 10.30742/jikw.v5i 2.338

Bahar, R., Arief, A. \& Sukriadi. 2012. Daya hambat ekstrak Na-alginat dari alga coklat jenis Sargassum Sp. terhadap proses pematangan buah mangga dan buah jeruk. Jurnal Indonesia Chimica Acta., 2(5):22-31.

Bastaman, S. 1989. Studies on Degradation and Extraction. England : The Queen's University of Belfast.

Hidayati, J.R., Ridlo, A. \& Pramesti, R. 2017. Aktivitas Antioksidan Ekstrak Rumput Laut Padina sp. Dari Perairan Bandengan Jepara dengan Metode Transfer Elektron. Buletin Oseanografi Marina., 6(1):46-52. doi: 10.14710/buloma.v6i1.15742

Hidayati, J.R., Yudiati, E., Pringgenies, D., Zaenal, A. \& Oktaviyanti, D.T. 2019. Antioxidant Activities, Total Phenolic Compound And Pigment Contents of Tropical Sargassum sp. Extract, Macerated In Different Solvents Polarity. Jurnal Kelautan Tropis., 22(1):73-80. doi: 10.14710/jkt.v22i1.4404

Hidayati, J.R., Yudiati, E., Pringgenies, D., Oktaviyanti, D.T. \& Kusuma, A.P. 2020. Comparative Study on Antioxidant Activities, Total Phenolic Compound and Pigment Contents of Tropical Spirulina platensis, Gracilaria arcuata and Ulva lactuca Extracted in Different Solvents Polarity. E3S Web of Conferences 147. doi: 10.1051/e3sconf/202014703012.

Jun, M., Fu, H.Y., Hong, J., Wan, X. \& Yang, C.S. 2003. Comparison of antioxidant activities of Isoflavones from kadzu root. Journal of Food Science., 68:2117-2122. doi: 10.1111 /j.1365-2621.20 03.tb07029.x

Kezia, O.A.L., Mariana, L.V., Ronaldo, A.R. \& Leticia, V.C. 2013. Proinflammatory activity of an alginate isolated from Sargassum vulgare. Carbohydrate Polymers., 92:414-420. doi: 10.1016/j.car bpol.2012.08.101

Kim, E.Y. \& Moudgil, K.D. 2017. Immunomodulation of Autoimmune Arthritis By Pro-inflammatory Cytokines.
Cytokine, 98:87-96. doi: 10.1016/j.cyto.20 17.04.012

Kozier. 1995. Buku Ajar Praktik Keperawatan Klinis. Jakarta : EGC.

Ko, S.C. 2011. Protective effect of Ecklonia cava on UVB-induced oxidative stress: in vitro and in vivo zebrafish model. Journal of Applied Phycology., 23:697-708. doi: 10.1007/s10811-010-9565-z

Kurahashi, T. \& Fujii, J. Roles of Antioxidative Enzymes in Wound Healing. Journal of Developmental Biology, 3(2):57-70. doi: 10.3390/jdb3020057

Laksanawati, R., Ustadi \& Husni, A. 2017. Pengembangan Metode Ekstraksi Alginat dari Rumput Laut Turbinaria Ornata. Jurnal Pengolahan Hasil Perikanan Indonesia, 20(2):362-369.

Latifi A.M., Nejad, E.S. \& Babavalian, H. 2015. Comparison of extraction different methods of sodium alginate from brown alga. Journal of Applied Biotechnology Reports., 2(2):251-255.

Maharani A.A., Husni, A. \& Ekantari, N. 2017. Karakteristik natrium alginat rumput laut cokelat Sargassum fluitans dengan metode ekstraksi yang berbeda. Jurnal Pengolahan Hasil Perikanan Indonesia., 20(3):478-487.

McDonnell, G. \& Russel, A.D. 1999. Antiseptics and Disinfectans: Activity, Action, and Resistance. Clinical Microbiology Reviews, 12(1):147-179.

Moubayed, N.M.S., Al Houri, H.J., Al Khulaifi, M.M. \& Al Farraj, D.A. 2017. Antimicrobial, Antioxidant Properties and Chemical Composition of Seaweed Collected from Saudi Arabia (Red Sea and arabian Gulf). Saudi Journal of Biological Science. doi: 10.1016/j.sjbs.2016.05.018

Nagoba, B.S., Selkar S.P., Wadher, B.J. \& Gandhi R.C. 2013. Acetic Acid Treatment of Pseudomonal Wound Infections - A Review. Journal of Infection and Public Health., 6:410-415. doi: 10.1016/j.jiph.2013. 05.005

Rahim, S.W. 2017. Respons Ikan Zebra Hitam (Dascyllus melanurus) terhadap Penggunaan Anaestesi Minyak Cengkeh sebagai Alat Bantu Penangkapan pada Skala Laboratorium. Marine Fisheries., 8(1): 51-61. doi: 10.29244/jmf.8.1.51-61

Richardson, R., Slanchev, K., Kraus, C., Knyphausen, P., Eming S. \& 
Hammerschmidt, M. 2013. Adult Zebrafish as a Model System for Cutaneous WoundHealing Research. Journal of Investigative Dermatology, 133:1655-1665. doi: 10.10 38/jid.2013.16

Richardson R., Metzger, M., Knypausen, P., Ramezani, T., Slanchev, K., Kraus, C., Schmelzer E. \& Hammerschmidt, M. Reepithelialization of cutaneous wounds in adult zebrafish combines mechanisms of wound closure in embryon,ic and adult mammals. Development., 143:2077-2088. doi: 10.1242/jcs.193763

Rizfa, M.S., Yudiati, E. \& Wijayanti, D.P. 2020. Improving The Antioxidant Activity of Sodium Alginate from Sargassum sp. by Thermal Heating and Chemical Methods. Jurnal Kelautan Tropis., 23(3): 284-290. doi: 10.14710/jkt.v23i3.8946

Sayuti, K. \& Yenrina, R. 2015. Antioksidan Alami dan Sintetik. Padang, Andalas University.

Sivaraman, A., Johnson, M., Parimelazhagan, T. \& Irudayaraj, V. 2013. Evaluation of antioxidant potential of ethanolic extracts of selected species of Selaginella. Indian Journal of Natural Products and Resources, 4(3):238-244.

Szekalska., Puciłowska, A., Szymańska, E., Ciosek, P. \& Winnicka, K. 2016. Alginate: Current Use and Future Perspectives in
Pharmaceutical and Biomedical Applications. International Journal of Polymer Science., pl-17. doi: 10.1155/20 16/7697031

Wang, C., Zang, C., Liu, L., Xi, Chen, B., Lie, Y. \& Du, J. 2017. Macrophage-Derivedmir155-Containing Exosomes Suppress Fibroblast Proliferation and Promote Fibroblast Inflammation during Cardiac Injury. Molecular Therapy., 25(1): 192-204. doi: 10.1016/j.ymthe.2016.09.001

Yudiati, E. \& Isnansetyo, A. 2017. Characterizing the Three Different Alginate Type of Sargassum siliquosum. Ilmu Kelautan: Indonesian Journal of Marine Sciences, 22(1):7-14. doi: 10.14710/ ik.jmms.22.1.7-14

Yudiati, E., Santosa, G.W, Tontowi, M.R., Sedjati, S., Supriyantini E. \& Khakimah, M. 2018a. Optimization of alginate alkaline extraction technology from Sargassum polycystum and its antioxidant properties. IOP Conf. Series: Earth and Environmental Science 139.

Yudiati, E., Pringgenies, D., Djunaedi, A., Arifin Z. \& Sudaryono, A. 2018b. Free Radical Scavenging of Low Molecular Weight Sodium Alginate (LMWSA) from Sargassum polycystum Produced by Thermal Treatment. Acuacultura Indonesiana, 9(1):21-27. doi: 10.21534/ai.v19i1.121 